\title{
Bimbingan Kelompok Dengan Permainan Monopede Untuk Meningkatkan Percaya Diri Peserta Didik Di SMA Negeri 1 Brebes
}

\author{
Dewi Ekasari \\ Guru Bimbingan dan Konseling
}

SMA Negeri 1 Brebes

Guru SMA Negeri 1 Brebes

\begin{abstract}
Abstrak
Percaya diri dibutuhkan untuk menunjang proses pembelajaran di sekolah, namun beberapa peserta didik mengalami ketidakmampuan dalam mengungkapkan pendapatnya dalam kelompok, selain itu bimbingan kelompok yang dilaksanakan masih kurang inovatif sehingga siswa kurang antusias. Tujuan dalam penelitian ini adalah meningkatkan percaya diri melalui bimbingan kelompok dengan permainan Monopede. Penelitian tindakan dilakukan dengan dua siklus. Sampel penelitian menggunakan purposive sampling dengan anggota kelompok heterogen yaitu 11 yang memiliki tingkat percaya diri rendah. Metode pengumpulan data yang digunakan pedoman wawancara, skala psikologi dan pedoman observasi. Hasil penelitian diperoleh, tingkat percaya diri anggota kelompok pada siklus I diperoleh $74,5 \%$ pada kondisi tinggi. Dari hasil tindakan siklus I belum mampu memenuhi indikator kinerja dalam penelitian ini, maka diberikan tindakan pada siklus II dengan hasil 90,9\% pada kondisi sangat tinggi tingkat percaya diri anggota kelompok. Disimpulkan bahwa percaya diri dapat ditingkatkan melalui bimbingan kelompok dengan permainan Monopede. Saran yang diberikan pada guru bimbingan konseling diharapkan memberikan inovasi dalam perlakuan (treatment) kepada peserta didik yang memiliki kemampuan dalam meningkatkan percaya diri.
\end{abstract}

Kata Kunci : Bimbingan Kelompok, Permainan Monopede, Percaya Diri

\begin{abstract}
Confidence is needed to support the learning process at school, but some students experience the inability to express their opinions when in the group, besides that the group of guidance that is implemented is still less innovative so that the students are less enthusiastic. The purpose of this study in increasing confidency through group of guidance with monopede games. The action research with two cycles. The research sample used purposive sampling and members of heterogeneous groups were 11 group members having low self-confidence. Data collection methods used were interview guidelines, psychological scales and observation guidelines. The results obtained, the level of confidence of group members in the first cycle was $74.5 \%$ in high condition. From the results of the first cycle of actions, it can be seen that it has not been able to meet the performance indicators in this study, therefore, the resercher gave the action in the second cycle with the results of a percentage of $90.9 \%$ in a very high condition level of confidence among group members. It was concluded that the confidence can be increased through group guidance with the Monopede game. The advice to counseling guidance teachers are expected to provide innovation in treatment to students who have the ability to increase self-confidence.
\end{abstract}

Keywords: Group Guidance, Monopede Games, Confidence 


\section{PENDAHULUAN}

Rasa percaya diri merupakan suatu keyakinan terhadap segala aspek yang dimiliki dan keyakinan tersebut membuatnya merasa mampu untuk bisa mencapai berbagai tujuan dalam hidupnya. Rasa percaya diri adalah keyakinan pada kemampuan-kemampuan sendiri, keyakinan pada adanya suatu maksud di dalam kehidupan, dan kepercayaan bahwa dengan akal budi mereka akan mampu melaksanakan apa yang mereka inginkan, rencanakan dan harapkan (Davies, 2004).

. Menurut Hakim (2005: 6) menyebutkan bahwa "rasa percaya diri adalah suatu keyakinan seseorang terhadap segala aspek kelebihan yang dimilikinya dan keyakinan tersebut membuatnya merasa mampu untuk bisa mencapai berbagai tujuan di dalam hidupnya." Berdasarkan pendapat para ahli di atas maka dapat disimpulkan bahwa percaya diri merupakan kesadaran individu akan kekuatan dan kemampuan diri yang dimilikinya, meyakini adanya rasa percaya diri dalam dirinya, merasa puas terhadap dirinya untuk mencapai tujuan serta dapat bersikap positif terhadap lingkungan yang dihadapinya.

Namun ketidakmampuan peserta didik dalam mengekspresikan diri akan berpengaruh pada kurangnya rasa percaya diri dan hal ini sangat berpengaruh pada tugas perkembangan peserta didik sehingga menghambat aktifitas sehari-hari.

Berdasarkan hasil observasi yang dilakukan peneliti saat memberikan bimbingan kelompok pada peserta didik kelas X IPA 2 memiliki ketidakmampuan dalam mengekspresikan diri sehingga mereka kurang percaya diri di kelas maupun di luar kelas. Hasil skala percaya diri yang diberikan kepada peserta didik di kelas X IPA 2 yang berjumlah 11 peserta didik sebagai bentuk kondisi awal diperoleh rata-rata terdapat $81,82 \%$ atau 9 peserta didik dalam ketegori rendah/tidak percaya diri, dan $18,2 \%$ atau 2 peserta didik dalam kategori memiliki kepercayaan diri tinggi. Hal ini dilihat dari indikator percaya diri yaitu memiliki keyakinan kemampuan diri, optimis, objektif, bertanggung jawab, rasional dan realistis. Selain itu kurangnya inovasi dalam pemberian layanan bimbingan kelompok yang dilakukan oleh guru bimbingan dan konseling, sehingga siswa merasa kurang tertarik terhadap bimbingan kelompok.

Bimbingan kelompok adalah suatu kegiatan yang dilakukan oleh sekelompok orang dengan memanfaatkan dinamika kelompok. Artinya, semua peserta dalam kegiatan kelompok saling berinteraksi, bebas mengeluarkan pendapat, menanggapi, memberi saran, dan lain sebagainya; apa yang dibicarakan itu semuanya bermanfaat untuk diri peserta yang bersangkutan sendiri dan untuk peserta lainnya (Prayitno, 1995: 178). Melalui bimbingan kelompok ini dimungkinkan akan dapat membantu anggota kelompok dalam membentuk komunikasi sosial dalam pemecahan masalah terutama untuk meningkatkan percaya diri setiap anggota kelompok. Menurut Prayitno (2004: 65) proses bimbingan kelompok terdiri atas beberapa tahap, antara lain 1) tahap pembentukan, 2) tahap peralihan, 3) tahap kegiatan, dan 4) tahap pengakhiran.

Perlunya inovasi dalam layanan bimbingan kelompok maka guru BK memberikan inovasi layanan yaitu berupa penggunaan media permainan Monopede (Monopoli Percaya Diri) dalam pelaksanaan bimbingan kelompok untuk meningkatkan percaya diri. Permainan Monopede dikembangkan dari permainan monopoli pada umumnya yang dimainkan oleh semua kalangan. Monopoli merupakan salah satu permainan papan yang sangat dikenal di dunia. Permainan ini 
dilakukan dengan cara melemparkan dadu secara bergiliran untuk memindahkan bidaknya, apabila ia mendarat di petak yang belum dimiliki oleh pemain lain, ia dapat membeli petak itu sesuai dengan harga yang tertera (Agus,C. 2011). Monopoli merupakan permainan yang memberikan kebebasan bagi setiap pemain untuk menggunakan strategi. Permainan monopoli dapat digunakan sebagai media pembelajaran yang inovatif dan lebih menarik.

Prosedur penggunaan media permainan Monopede adalah sebagai berikut:

1) Permulaan

Pemain mengocok dadu secara bergiliran, angka yang terbanyak main dahulu. Permainan dimulai dari petak START. Setelah itu bidak-bidak pemain dijalankan bergiliran sesuai angka dadu ke petak menutut anak panah.

2) Kartu Action

Bidak-bidak yang berjalan akan melewati kartu Action, maka pemilik bidak tersebut harus menampilkan apa yang ada dalam kartu Action.

3) Kartu Ungkap Diri

Bidak-bidak yang berjalan akan melewati kartu Ungkap Diri, maka pemilik bidak tersebut harus berani mengungkapkan diri sesuai dengan perintah yang ada pada kartu Ungkap Diri. Kartu ungkap diri ini berisi mengenai hal-hal yang menjadi kelemahan maupun kelebihan diri.

4) Uang-uangan

Pemilik bidak yang melakukan Action atau berani menjawab kartu Ungkap Diri maka akan diberikan reward berupa uang-uangan. Hal ini sebagai penyemangat.

Pengembangan media Monopede terdapat nilai-nilai yang diperoleh yaitu kemampuan berkomunikasi, berinteraksi dalam kelompok, berani tampil di hadapan orang lain, dan semangat untuk melakukan berbagai aktifitas sehingga peserta didik merasa nyaman dan bahagia.

Berdasarkan latar belakang tersebut di atas maka dalam penelitian ini perlu adanya inovasi dalam memberikan layanan bimbingan kelompok agar dapat membantu peserta didik yang memiliki kepercayaan diri rendah karena berakibat pada tingkah laku sehingga mengganggu kehidupan efektif sehari-hari. Salah satu media yang diguanakan dalam bimbingan kelompok ini adalah media Monopede (Monopoli Percaya Diri) sebagai media untuk mempermudah anggota kelompok untuk mengungkapkan pendapatnya sehingga kepercayaan diri anggota kelompok menjadi meningkat.

Tujuan dari penelitian ini mengetahui penerapan bimbingan kelompok untuk meningkatkan percaya diri, menerapkan tindakan bimbingan kelompok melalui permaianan Monopede untuk meningkatkan percaya diri, dan mengetahui tingkat percaya diri peserta didik setelah mendapatkan tindakan bimbingan kelompok dengan permainan Monopede.

\section{METODE}

Jenis penelitian ini adalah penelitian tindakan atau Penelitian Tindakan Bimbingan dan Konseling (PTBK). Analisis pada Penelitian Tindakan Bimbingan Konseling dilakukan dengan metode kuantitatif dan kualitatif. Menurut Arikunto, tahapan dalam penelitian tindakan yaitu; 1) perencanaan, 2) pelaksanaan, 3) pengamatan, dan 4) refleksi (Arikunto, 2006: 97). Penelitian dilaksanakan dengan dua siklus yaitu siklus I dan siklus II. Setiap siklus diawali dengan a) Perencanaan, b) Action yang 
meliputi : (1) Tahap Pembentukan, (2) Tahap Peralihan, (3) Tahap Kegiatan, (4) Tahap Pengakhiran, c) Observasi, dan d) Refleksi.

Sampel penelitian menggunakan purposive sampling yaitu 11 orang peserta didik yang memiliki tingkat percaya diri rendah, sedang dan tinggi. Teknik pengumpulan data yang digunakan dalam penelitian ini adalah (a) Teknik wawancara untuk mengumpulkan data tentang rasa percaya diri pada kondisi awal, (b) teknik observasi/pengamatan untuk mengumpulkan data tentang rasa percaya untuk mengetahui perubahan yang terdapat dalam situasi atau pada perilaku ataupun kegiatan yang sedang diamati pada saat proses berlangsung. Indikator kinerja dalam penelitian tindakan ini adalah adanya peningkatan kepercayaan diri yang dimiliki oleh peserta didik sebesar $90 \%$ dilihat dari indikator kepercayaan diri yang ingin dicapai. Indikator kinerja tersebut meliputi: (1) keyakinan akan kemampuan diri, (2) optimis, (3) objektif, (4) bertanggung jawab, (5) rasional dan realistis.

\section{HASIL}

Pelaksanaan bimbingan kelompok yang dilakukan oleh guru bimbingan dan konseling (peneliti) kepada anggota kelompok yaitu kelas X MIPA 2 SMA Negeri 1 Brebes Tahun Pelajaran 2019/2020 belum menggunakan metode dan media yang representatif, masih menggunakan metode ceramah, sehingga peserta didik kurang tertarik, merasa bosan, kurang aktif saat proses bimbingan kelompok dan berakibat pada hasil pelaksanaan bimbingan kelompok yang belum mampu meningkatkan kepercayaan diri peserta didik. Dari data awal diperoleh hasil kondisi awal kepercayaan diri anggota kelompok sebanyak $9(81,8 \%)$ anggota kelompok berada pada kategori rendah, dan 2 $(18,2 \%)$ anggota kelompok pada kategori tinggi. Adapun anggota kelompok dalam bimbingan kelompok ini adalah hasil skala pretes percaya diri peserta didik dapat terlihat dalam tabel berikut :

Tabel 1.

Tingkat Percaya Diri Anggota Kelompok Pada Kondisi awal

\begin{tabular}{cccccc}
\hline No. & Interval Prosentase & $\%$ & Frekuensi & $\%$ & Kriteria \\
\hline 1. & $84 \%<\% \leq 100 \%$ & $0 \%$ & 0 & $0 \%$ & Sangat Tinggi \\
2. & $68 \%<\% \leq 84 \%$ & $8 \%$ & 2 & $18,2 \%$ & Tinggi \\
3. & $52 \%<\% \leq 68 \%$ & $0 \%$ & 0 & $0 \%$ & Sedang \\
4. & $36 \%<\% \leq 52 \%$ & $36 \%$ & 9 & $81,8 \%$ & Rendah \\
5. & $20 \%<\% \leq 36 \%$ & $0 \%$ & 0 & $0 \%$ & Sangat Rendah \\
\hline
\end{tabular}

Hasil deskriptif prosentase skala percaya diri peserta didik pada kondisi awal tersebut dapat disajikan dalam bentuk grafik di bawah ini: 


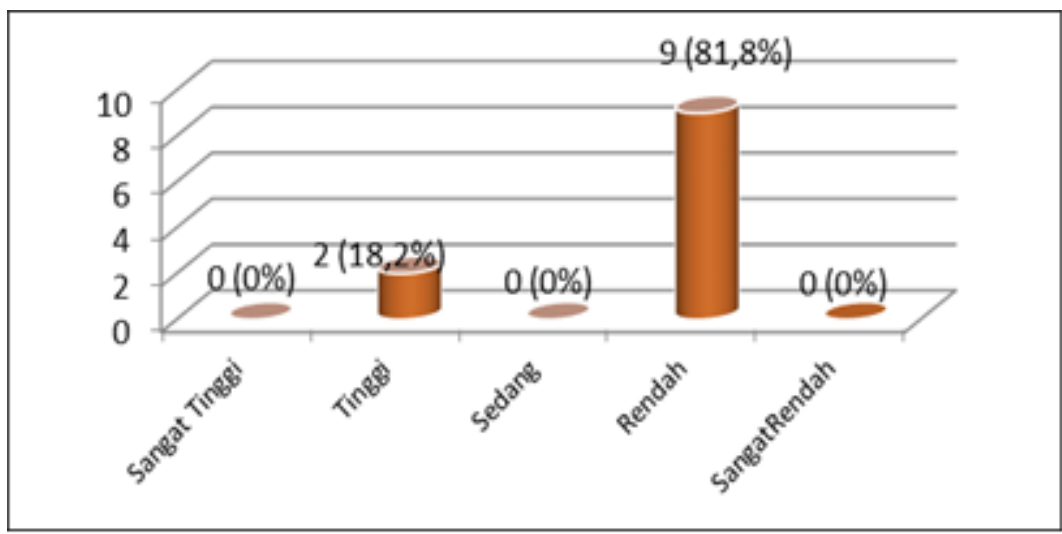

Grafik 1.

Hasil Skala Percaya Diri pada kondisi awal

Dari grafik 1 memperlihatkan bahwa tingkat percaya diri peserta didik kelas X MIPA 2 SMA N 1 Brebes semester 1 terdapat $81,9 \%$ atau 9 orang anggota kelompok memiliki percaya diri yang rendah, dan hanya $18,2 \%$ atau 2 orang anggota kelompok memiliki tingkat percaya diri tinggi.

\section{Siklus I}

Berdasarkan hasil evaluasi observasi pelaksanaan bimbingan kelompok untuk meningkatkan percaya diri pada siklus I dapat dilihat pada tabel 2 dan grafik 2, sebagai berikut:

Tabel 2.

Profil Tingkat Percaya Diri pada Siklus I

\begin{tabular}{ccccc}
\hline No. & Interval Prosentase & Frekuensi & $\%$ & Kriteria \\
\hline 1. & $84 \%<\% \leq 100 \%$ & 0 & $0 \%$ & Sangat Tinggi \\
2. & $68 \%<\% \leq 84 \%$ & 7 & $74,5 \%$ & Tinggi \\
3. & $52 \%<\% \leq 68 \%$ & 0 & $0 \%$ & Sedang \\
4. & $36 \%<\% \leq 52 \%$ & 4 & $25,5 \%$ & Rendah \\
5. & $20 \%<\% \leq 36 \%$ & 0 & $0 \%$ & Sangat Rendah \\
\hline
\end{tabular}

Berdasarkan hasil penghitungan prosentase tingkat percaya diri di atas maka dapat diketahui bahwa tingkat percaya diri anggota kelompok setelah diberikan tindakan bimbingan kelompok dengan media permainan Monopede pada siklus I mengalami peningkatan, artinya ada perbedaan antara evaluasi hasil pada kondisi awal dengan evaluasi hasil tindakan pada siklus I. Hal ini dapat diketahui dari 11 orang anggota kelompok yang mengisi skala percaya diri setelah diberikan tindakan berupa bimbingan kelompok dengan media permainan Monopede diperoleh hasil rata-rata skor yaitu $74,5 \%$ dengan kategori tinggi. Hasil deskriptif prosentase skala keputusan karir peserta didik pada siklus I tersebut dapat disajikan dalam bentuk grafik di bawah ini:

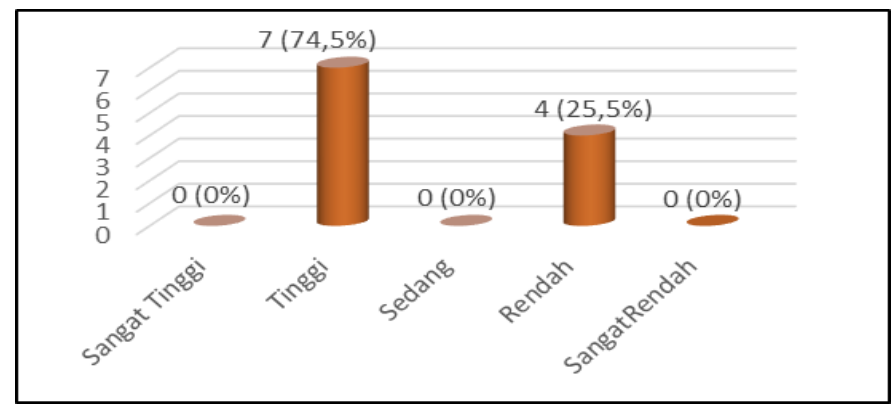

Grafik 2.

Profil Peningkatan Percaya Diri Anggota Kelompok Pada Siklus I 
Berdasarkan grafik 2 tersebut dapat dilihat bahwa peningkatan percaya diri anggota kelompok masih belum memenuhi indikator keberhasilan dalam peningaktan percaya diri, hal ini masih terlihat bahwa ada $7(74,5 \%)$ orang anggota dalam kategori tinggi dan $4(25,5 \%)$ orang anggota dalam kategori rendah.

Tabel 3

Hasil Prosentase Pada Siklus I dan Siklus II

\begin{tabular}{cccccc}
\hline \multirow{2}{*}{ No } & \multirow{2}{*}{ Interval } & Kriteria & $\begin{array}{c}\mathrm{F} \\
\text { Siklus I }\end{array}$ & $\begin{array}{c}\mathrm{F} \\
\text { Siklus II }\end{array}$ & $\begin{array}{c}\mathrm{F} \\
\text { Peningkatan }\end{array}$ \\
\hline 1. & $84 \%<\% \leq 100 \%$ & $\mathrm{ST}$ & 0 & 0 & 0 \\
2. & $68 \%<\% \leq 84 \%$ & $\mathrm{~T}$ & 2 & 7 & 5 \\
3. & $52 \%<\% \leq 68 \%$ & $\mathrm{~S}$ & 0 & 0 & 0 \\
4. & $36 \%<\% \leq 52 \%$ & $\mathrm{R}$ & 9 & 4 & -5 \\
5. & $20 \%<\% \leq 36 \%$ & SR & 0 & 0 & 0 \\
\hline \multicolumn{5}{c}{ Berdasarkan hasil perbandingan kondisi awal dengan tindakan pada siklus I maka ada }
\end{tabular}
perbedaan dan peningkatan. Hal ini dapat dilihat dari penghitungan pada evaluasi kondisi awal dengan melaksanakan bimbingan kelompok untuk meningkatkan percaya diri pada 11 orang anggota kelompok diperoleh hasil terdapat 7 (74,5\%) orang anggota dalam kategori tinggi dan $4(25,5 \%)$ orang anggota dalam kategori rendah.

Perubahan perilaku pada siklus I dapat dilihat dari hasil pengamatan pemimpin kelompok pada proses bimbingan kelompok yaitu adanya kenyamanan dan saling terbuka menyampaikan pendapat dengan penuh percaya diri, memiliki motivasi yang tinggi untuk menjadi lebih baik dalam berinteraksi sosial, dan meningkatkan semangat dalam belajar. Jika dilihat dari hasil pada siklus I, maka indikator kinerja yang dihasilkan belum terpenuhi. Maka dalam penelitian tindakan ini peneliti melanjutkan pemberian tindakan pada siklus II untuk mencapai target indikator kinerja yang diharapkan.

\section{Siklus II}

Peneliti melanjutkan dengan pemberian tindakan pada siklus II, hasil pengamatan tindakan bimbingan kelompok dengan permainan Monopede untuk meningkatkan percaya diri peserta didik dapat dilihat dalam tabel dan grafik berikut:

Tabel 3.

Tingkat Percaya Diri Anggota Kelompok Pada Siklus II

\begin{tabular}{ccccc}
\hline No. & Interval Prosentase & Frekuensi & $\%$ & Kriteria \\
\hline 1. & $84 \%<\% \leq 100 \%$ & 10 & $90,9 \%$ & Sangat Tinggi \\
2. & $68 \%<\% \leq 84 \%$ & 1 & $9,1 \%$ & Tinggi \\
3. & $52 \%<\% \leq 68 \%$ & 0 & $0 \%$ & Sedang \\
4. & $36 \%<\% \leq 52 \%$ & 0 & $0 \%$ & Rendah \\
5. & $20 \%<\% \leq 36 \%$ & 0 & $0 \%$ & Sangat Rendah \\
\hline
\end{tabular}

Berdasarkan hasil penghitungan prosentase tingkat percaya diri di atas maka dapat diketahui bahwa tingkat percaya diri anggota kelompok setelah diberikan tindakan bimbingan kelompok dengan media permainan Monopede pada siklus II mengalami peningkatan, terdapat 10 (90,9\%) orang anggota kelompok kategori Sangat Tinggi. Proses bimbingan kelompok dilakukan dengan metode experiential learning, artinya memberikan kesempatan kepada anggota kelompok untuk berpendapat sesuai dengan pengalaman pribadinya berkaitan dengan materi/topik yang diberikan. Hasil deskriptif 
prosentase skala keputusan karir peserta didik pada siklus II tersebut dapat disajikan dalam bentuk grafik di bawah ini:

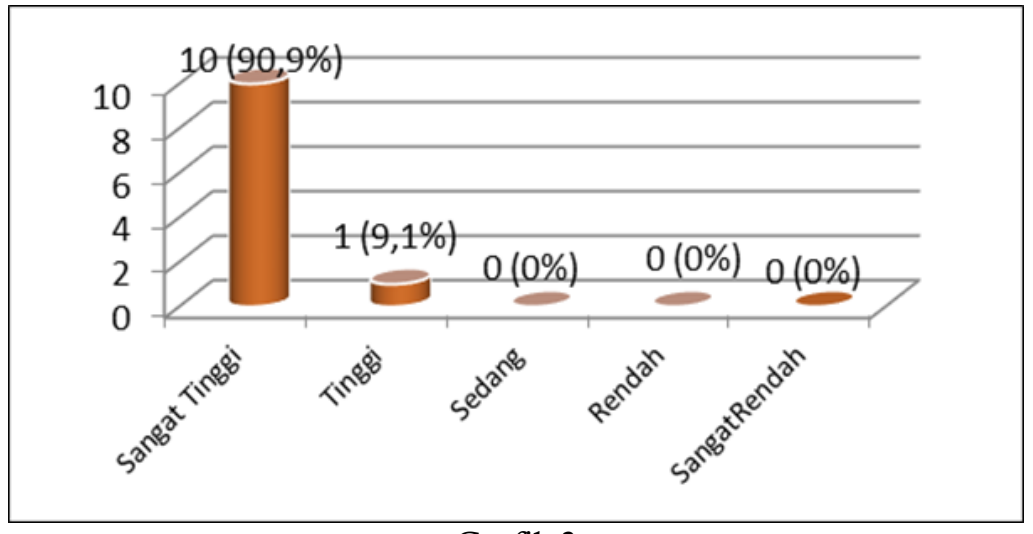

Grafik 3

Profil Peningkatan Percaya Diri Anggota Kelompok Pada Siklus II

Berdasarkan hasil postest dan hasil observasi tersebut, maka pemberian tindakan bimbingan kelompok dengan media permainan Monopede ternyata mampu meningkatkan percaya diri peserta didik. Namun dari data tersebut di atas dianggap masih belum optimal dalam perolehan hasilnya. Penelitian ini memberikan kategori dan capaian indikator kinerja berjumlah $89 \%$ atau pada kategori sangat tinggi.

Dari hasil tingkat percaya diri dan hasil observasi bimbingan kelompok, maka dapat dilihat perbedaan dari kedua siklus yang dilakukan yaitu pada siklus I dan siklus II berikut ini:

Tabel 4.

Hasil Prosentase Pada Siklus I dan Siklus II

\begin{tabular}{cccccccc}
\hline No & Interval & Kriteria & $\begin{array}{c}\mathrm{F} \\
\text { Siklus I }\end{array}$ & $\begin{array}{c}\% \\
\text { Siklus I }\end{array}$ & $\begin{array}{c}\mathrm{F} \\
\text { Siklus II }\end{array}$ & $\begin{array}{c}\% \\
\text { Siklus II }\end{array}$ & $\begin{array}{c}\text { Skor } \\
\text { Peningkatan }\end{array}$ \\
\hline 1. & $84 \%<\% \leq 100 \%$ & $\mathrm{ST}$ & 0 & $0 \%$ & 10 & $90,9 \%$ & $90,9 \%$ \\
2. & $68 \%<\% \leq 84 \%$ & $\mathrm{~T}$ & 7 & $74,5 \%$ & 1 & $9,1 \%$ & $-65,5 \%$ \\
3. & $52 \%<\% \leq 68 \%$ & $\mathrm{~S}$ & 0 & $0 \%$ & 0 & $0 \%$ & $0 \%$ \\
4. & $36 \%<\% \leq 52 \%$ & $\mathrm{R}$ & 4 & $25,5 \%$ & 0 & $0 \%$ & $-25,5 \%$ \\
5. & $20 \%<\% \leq 36 \%$ & SR & 0 & $0 \%$ & 0 & $0 \%$ & $0 \%$
\end{tabular}

Penjelasan di atas dapat terlihat dalam sebuah grafik peningkatan keputusan karir setelah diberikan bimbingan klasikal bidang karir pada siklus I dengan siklus II yaitu sebagai berikut:

Grafik 4.4

Profil Grafik Perbandingan Tingkat Percaya Diri pada Siklus I dan Siklus II

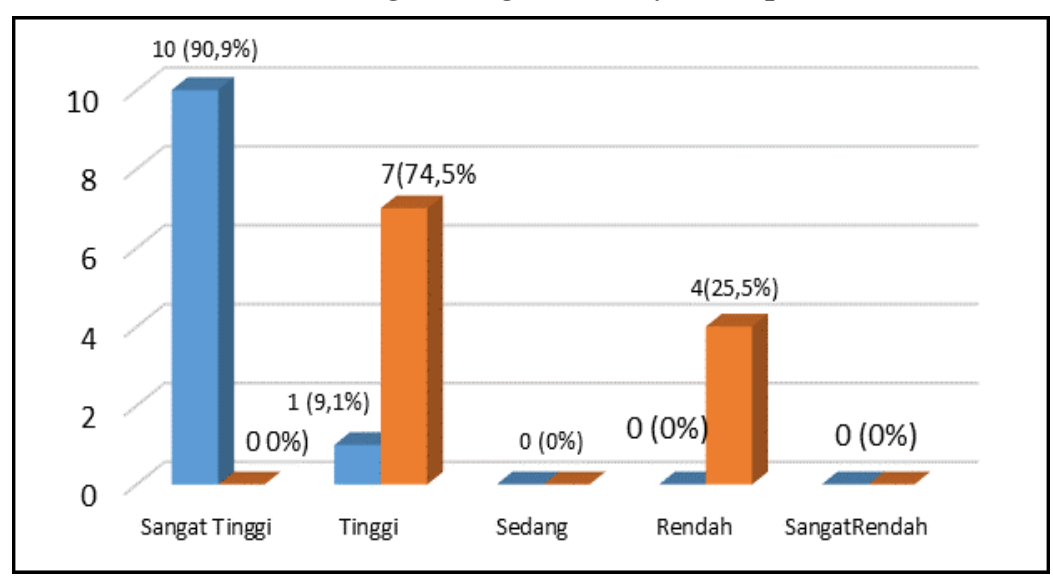


Berdasarkan hasil evaluasi dan hasil observasi tersebut, maka pemberian tindakan bimbingan kelompok dengan media permainan Monopede ternyata mampu meningkatkan percaya diri peserta didik. Hasil perbedaan peningkatan percaya diri anggota kelompok pada siklus I dan siklus II sangat signifikan, hal ini ditunjukkan dengan perolehan pada siklus II ada 10 (90,9\%) orang anggota kelompok yang memiliki tingkat percaya diri pada kategori sangat tinggi, dan $1(9,1 \%)$ orang anggota kelompok pada kategori tinggi. Tindakan bimbingan kelompok dengan media permainan Monopede untuk meningkatkan percaya diri peserta didik mencapai indikator kinerja yang diharapkan dalam penelitian ini.

\section{PEMBAHASAN}

Berdasarkan data awal maka diperoleh hasil rata-rata dari skala tingkat percaya diri peserta didik yaitu pada kategori rendah $(63,4 \%)$. Dari hasil tersebut maka peneliti berusaha memperbaiki proses pelaksanaan bimbingan kelompok yang sudah berjalan, karena pelaksanaan bimbingan kelompok sebelumnya kurang inovatif, kreatif dan terlihat membosankan bagi peserta didik, sehingga berpengaruh pada hasil tingkat percaya diri yang menjadi tujuan dalam pelaksanaan bimbingan kelompok untuk meningkatkan percaya diri peserta didik.

Berdasarkan uraian di atas peneliti memperbaiki layanan bahwa: a) melalui bimbingan kelompok dengan permainan Monopede dapat meningkatkan percaya diri peserta didik kelas X MIPA 2 SMA Negeri 1 Brebes semester 1 tahun pelajaran 2019/2020 dilihat dari kondisi awal yang masih rendah ke kondisi tingkat percaya diri yang tinggi, b) melalui kegiatan bimbingan kelompok dengan permainan Monopede menunjukkan dari kondisi awal sebanyak 9 orang anggota kelompok berada pada kategori rendah (prosentase antara 44\%-63\%) setelah diberikan tindakan maka ada peningkatan menjadi $10(90,9 \%)$ orang anggota kelompok yang memiliki tingkat percaya diri pada kategori sangat tinggi.

Hal ini artinya anggota kelompok sudah mampu memunculkan percaya diri yang dilihat dari indikator percaya diri: keyakinan pada kemampuan diri, optimis, objektif, bertanggungjawab, dan realistis. Seperti yang diungkapkan oleh Surya (2007: 56) bahwa rasa percaya diri merupakan sikap mental optimisme dari kesanggupan anak terhadap kemampuan diri untuk menyelesaikan segala sesuatu dan kemampuan diri untuk melakukan penyesuaian diri pada situasi yang dihadapi.

Hasil pada tindakan bimbingan kelompok dengan media permainan Monopede pada siklus I dan siklus II dapat dikatakan mampu untuk meningkatkan percaya diri peserta didik.

\section{SIMPULAN}

Pelaksanaan bimbingan kelompok dengan media permainan Monopede untuk meningkatkan percaya diri peserta didik kelas X MIPA 2 semester 1 dari hasil evaluasi diperoleh prosentase pada siklus I sebesar $74,5 \%$ atau sebanyak 7 orang anggota kelompok memiliki tingakat percaya diri dengan kategori tinggi, artinya bahwa peserta didik sudah mampu memahami kelebihan dan kekurangan diri, optimis, objektif, bertanggung jawab dan realistis. Namun hasil tersebut belum memenuhi kriteria 
indikator kinerja yang diharapkan, dan belum optimal peningkatannya. Sehingga diberikan tindakan kembali pada siklus II dengan jumlah responden 11 orang maka diperoleh hasil 90,9\% atau sebanyak 10 orang anggota kelompok memiliki tingkat percaya diri pada kategori Sangat Tinggi.

Tingkat percaya diri anggota kelompok setelah diberikan tindakan bimbingan kelompok dengan permaianan Monopede sebanyak dua siklus mengalami peningkatan. Hal ini diartikan bahwa bimbingan kelompok dengan media permainan Monopede secara signifikan dapat meningkatkan percaya diri peserta didik.

Saran yang diberikan dalam pelaksanaan penelitian ini adalah : 1) Bagi guru bimbingan dan konseling diharapkan dapat memberikan perlakuan (treatment) atau perhatian khusus kepada peserta didik yang memiliki kemampuan percaya diri rendah, 2) Bagi peserta didik diharapkan untuk selalu bersosialisasi terhadap lingkungannya serta terbuka dalam mengungkapkan pendapatnya, 3) Bagi diharapkan agar dapat memfasilitasi konselor sekolah sehingga dapat melaksanakan kegiatan-kegiatan bimbingan dan konseling dengan berbagai media dan inovasi terutama bimbingan kelompok untuk meningkatkan percaya diri peserta didik.

\section{DAFTAR PUSTAKA}

Arikunto, Suharsimi. 2006. Prosedur Penelitian (Suatu Pendekatan Praktik). Jakarta: RINEKA CIPTA.

Davies, P. 2004. Meningkatkan Rasa Percaya Diri. Jogjakarta: Torrent Books

Hakim, T. 2005. Mengatasi Rasa Tidak Percaya Diri. Jakarta : Puspa Swara.

N, Agus Cahyo. 2011. Gudang Permainan Kreatif Khusus Asah Otak Kiri Anak. Jogjakarta: FlashBooks

Prayitno. 1995. Layanan Bimbingan Dan Konseling Kelompok (Dasar dan Profil). Jakarta: GHALIA INDONESIA.

Surya, H. 2007. Percaya Diri Itu Penting. Jakarta : Gramedia. 